\title{
A PHOTOGRAPHIC SURVEY OF CERTAIN AREAS OF SEA FLOOR NEAR PLYMOUTH
}

\author{
By H. G. Vevers, M.A., D.Phil. \\ Zoologist at the Plymouth Laboratory
}

(Plate I and Text-figs. I-2)

\section{INTRODUCTION}

The present work is a continuation of that carried out in the period July I949-October I950 (Vevers, I95I). The underwater photographic apparatus has been modified and improved; the main changes are (a) the lamps are now carried on a tubular metal semicircle instead of on a ring of strip metal, (b) the bottom of the pole is bent at an angle to the main pole, and $(c)$ an improved junction box fixed above the foot switch allows the main electrical cable to be detached completely from the remainder of the apparatus. These modifications can be seen in Text-fig. I.

The apparatus is still capable of taking a series of photographs, each $\mathrm{I} \mathrm{m.}{ }^{2}$ in area or less, and in the present work the camera has actually been set at a distance of $\mathrm{I} \mathrm{m}$. from the ground so that each picture covers an area of $\frac{1}{4} \mathrm{~m} .{ }^{2}(50 \times 50 \mathrm{~cm}$.). This lower position of the camera is also shown in Text-fig. I.

There is no doubt that with the camera in this lower position ( $\mathrm{I} \mathrm{m}$. from the ground) the definition of the photographs is greatly improved. This may be partly due to a reduction in the absolute amount of suspended particulate matter between the camera lens and the object.

The length of pole above the camera (in its lower position) might appear to be unnecessary, but in practice it has been found that this helps in steadying the whole apparatus when submerged.

In the previous work, using this apparatus, photographs were taken in four distinct areas near Plymouth, namely:

(a) Near Station $\mathrm{L}_{4}$, muddy sand with gravel patches, $55 \mathrm{~m}$.

(b) South and" south-west of Eddystone, 2-4 miles, clean sand, $70 \mathrm{~m}$.

(c) South-east of Looe Island, muddy sand and gravel, $50 \mathrm{~m}$.

(d) South-west of Looe Island, muddy sand and gravel, $54 \mathrm{~m}$.

No further work has yet been done in areas $(b)$ and $(c)$, but additional series of photographs have been taken in areas $(a)$ and $(d)$. Photographs have also been taken in two new areas:

(i) South-west of Rame Head, 2-3 miles.

(ii) North-west of Eddystone, $\frac{3}{4}$ mile. 
The results obtained during the period November I950 to August I95I are given below.

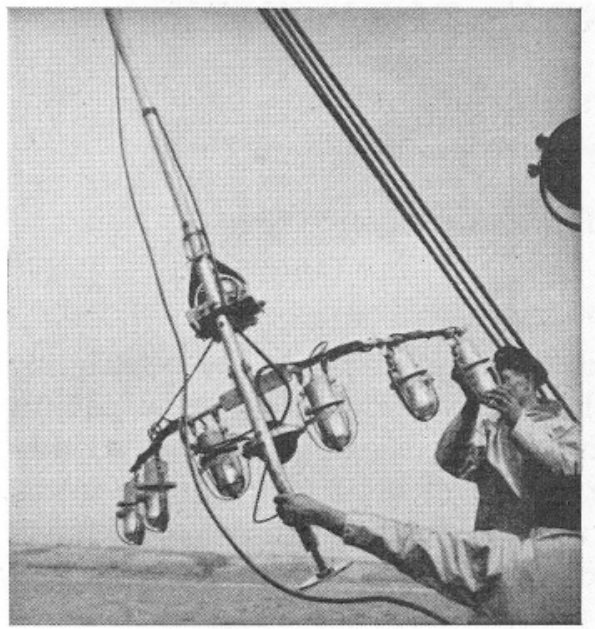

1

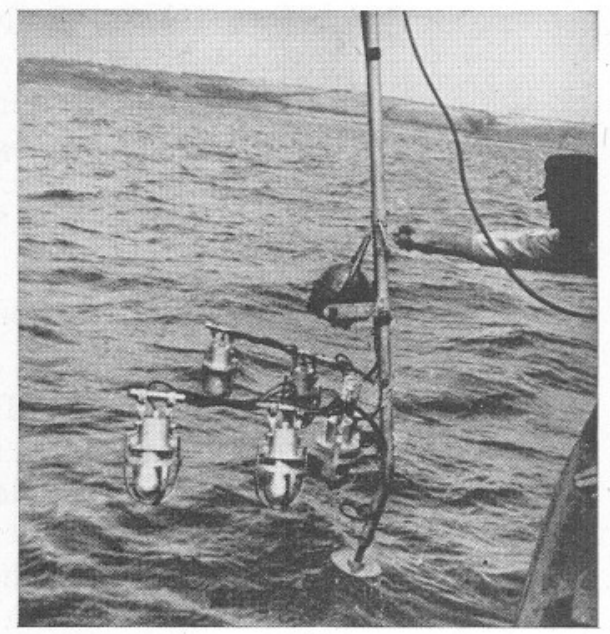

2

Text-fig. I. Underwater photographic apparatus hoisted over side of R.V. Sabella, showing new arrangement of photoflood lamps.

Text-fig. 2. Lowering the apparatus into the water. The camera case is in the lower position, to take a series of $\frac{1}{4} \mathrm{~m} .{ }^{2}$ photographs of the sea bottom.

Area South-west of Rame Head, 2-3 Miles, Depth $50 \mathrm{M}$.

A total of $\mathrm{I} 67$ photographs, each $\frac{1}{4} \mathrm{~m} .{ }^{2}$ in area, were taken along the transect Rame Head: $058^{\circ} \mathrm{T}$., distance $2 \cdot 2^{\prime}$; $058^{\circ} \mathrm{T}$., $2 \cdot 8^{\prime}$; $050^{\circ} \mathrm{T}$., $3.5^{\prime}$. On two photographs there were 17 empty Turritella shells ( 9 on one and 8 on the other), but there were no living epifaunal animals in any of the pictures. The bottom was soft mud, and in many of the photographs the surface showed slight but distinct ripple marks. The area is known locally as the Rame Mud and the characteristic fauna normally dredged there consists almost entirely of burrowing forms (Cucumaria elongata, Psammosolen (Azor) chamasolen, Melinna palmata). It is therefore not surprising that epifaunal animals should be more or less absent from this area.

\section{AREa of Station $\mathrm{L}_{4}$}

The new series of photographs in this area were taken along the following transects:

24. xi. 50. Penlee Point: $029^{\circ}$ T., $4 \cdot 9^{\prime} ; 033^{\circ}$ T., $4^{\cdot} 8^{\prime} ; 037^{\circ}$ T., $4^{\cdot} 8^{\prime} ; 039^{\circ}$ T., 5.0'; $043^{\circ}$ T., $4 \cdot 7^{\prime}$; $044^{\circ}$ T., $4 \cdot 7^{\prime}$.

I5. ii. 51. Penlee Point: $030^{\circ}$ T., $4 \cdot 9^{\prime}$; $035^{\circ}$ T., 5.2' ; $040^{\circ} \mathrm{T} ., 5 \cdot 2^{\prime}$; $050^{\circ} \mathrm{T} ., 3 \cdot 5^{\prime}$. 26. iv. 51. Looe Island; $310^{\circ} \mathrm{T}$., 6.3'; $309^{\circ} \mathrm{T} ., 6 \cdot 6^{\prime} ; 309^{\circ} \mathrm{T}$., 6.8'. 
Transect of 24 November 1950. Six films were taken, of which the first four were very close to one of the previous transects in this area (24 August 1949) (Vevers, I951, p. I05). These four films showed a uniformly poor fauna, similar to that already recorded for this area. A detailed count of the epifauna on I2I interpreted photographs (covering a total area of $30 \mathrm{~m} .^{2}$ ) gave the following figures: 9 Ophiura texturata, 3 Asterias rubens, 2 Marthasterias glacialis, 2 Chlamys opercularis, and a single specimen each of a hydroid, a burrowing anemone and Trigla sp. There were also three distinct tracks, probably made by an animal dragging its body along the surface of the bottom.

The first half of the fifth film showed the same type of poor epifauna, but at a point about $\frac{1}{4}$ mile north of the previous transect (24 August 1949) the nature of the fauna changed without any visible corresponding change in the nature of the bottom. In the last half of this film and in the first half of the

\section{TABLE I}

\begin{tabular}{|c|c|c|c|}
\hline Film & $\begin{array}{l}\text { Total of } \frac{1}{4} \mathrm{~m} .^{2} \\
\text { frames } \\
\text { interpreted }\end{array}$ & $\begin{array}{l}\text { Total of } \frac{1}{4} \mathrm{~m} .^{2} \\
\text { frames with } \\
\text { O. fragilis }\end{array}$ & $\begin{array}{l}\text { Total number } \\
\text { of } O \text {. fragilis }\end{array}$ \\
\hline I & 29 & - & - \\
\hline II & 23 & I & 3 \\
\hline III & $3 I$ & 2 & I6 \\
\hline IV & $2 \mathrm{I}$ & 5 & 35 \\
\hline $\mathrm{V}$ & 36 & 27 & 436 \\
\hline VI & 30 & - & - \\
\hline
\end{tabular}

sixth film nearly every frame showed crowded Ophiothrix fragilis. In thirtyone interpreted frames (each $\frac{1}{4} \mathrm{~m} .{ }^{2}$ ) there were $547 \mathrm{O}$. fragilis and 2 Ophiocomina nigra, giving a mean density of 70 brittle-stars per $\mathrm{m} .{ }^{2}$. In the second half of the sixth film there were only four frames showing Ophiothrix fragilis. All six films in this area showed a bottom of muddy sand with gravel, but it is probable that the last few photographs of the sixth were taken near the southern edge of the Rame Mud as they showed patches of bottom with empty shells of Dentalium and Turritella.

Transect of I5 February I95I. Six films were taken, five of them to the south of the transect of 24 August 1949, and the sixth film to the north. Here again, the majority of the $170 \frac{1}{4} \mathrm{~m} .{ }^{2}$ frames interpreted showed only a poor fauna. The total numbers of epifaunal animals, excluding Ophiothrix fragilis, in this part of the area were: 6 Ophiura texturata, I Marthasterias glacialis, 3 Asterias rubens, 4 Chlamys opercularis, I Pecten maximus, I2 Eupagurus prideauxi, I Portunus sp., I burrowing anemone and I4 clumps of Cellaria sp. This transect has also cut across a dense population of Ophiothrix fragilis, whose distribution is given in Table I.

The group of brittle-stars found on this transect is only $\frac{3}{4}$ mile west of the population photographed in the transect of 24 November 1950, and it is probable that both samples belong to the same large aggregation. Both these 
groups of $O$. fragilis (transects of 24 November I950 and I5 February I95I) did, in fact, occur in the neighbourhood of the first transect (24 August I949) photographed in this area, but which did not show any specimens of $O$. fragilis. It is possible then that the ophiuroid population found in 1950 and I95I was new to this locality, but it is more likely that the 1949 transect in this area just missed it.

Transect of 26 April I95I. Three films were taken along this transect which lay to the north-west of the previous two transects. The bottom was muddy sand with patches of fine gravel (see Pl. I, fig. 8). The epifauna, as shown by the photographs, was very poor, and the total of eighty-nine frames, representing $22 \mathrm{~m} .^{2}$ of the bottom, showed only 7 hydroids, 3 clumps of Cellaria sp., 4 burrowing anemones, I small crab, and I narrow track.

\section{Area South of Looe Island}

Photographs were taken along two transects:

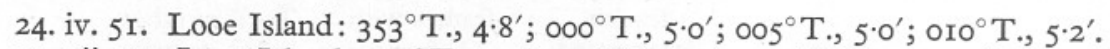

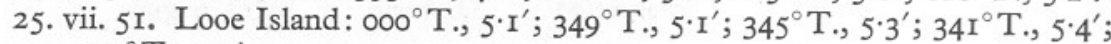
$342^{\circ} \mathrm{T} ., 5^{\circ} \mathrm{O}^{\prime}$.

Transect of 24 April 1951. This transect of four films ran from east to west and crossed the previous transect photographed in this area on 2 August 1950. The first film showed a bottom of sand and muddy sand and gravel with a very poor epifauna. On the second and third films the pictures showed a population of Ophiothrix fragilis somewhat less dense than that photographed on 2 August 1950. The total numbers of animals counted on this part of the transect (50 $\frac{1}{4} \mathrm{~m} .^{2}$ frames) was: $706 \mathrm{O}$. fragilis, I Ophiocomina nigra, 2 Chlamys opercularis, and I specimen each of Pecten maximus, Marthasterias glacialis, and a hydroid. The density of Ophiothrix fragilis was therefore about 56 individuals per $\mathrm{m}^{2}$. The fourth film of this transect showed no aggregations of brittle-stars except on two frames, and the only other animals recorded were 3 Chlamys opercularis and I swimming crab (Portunus sp.).

Transect of 25 Fuly I95I. This transect of four films ran to the east of the previous transect, and covered a distance of about $2 \frac{1}{4}$ miles. Nearly every frame contained a large number of Ophiothrix fragilis, denser in numbers than in the previous transect (see Pl. I, figs. I-4):

$$
\begin{array}{cccc}
\text { Total no. of } & \text { No. of frames } & \text { Total no. of } & \text { Mean no. of } \\
\text { frames } & \text { with O. fragilis } & \text { O. fragilis } & \text { per } \frac{1}{4} \mathrm{~m}^{2} \text { frame } \\
\text { I Io } & 99 & 3 \text { I } 43 & 32
\end{array}
$$

These photographs therefore show a mean density of over I20 O. fragilis per $\mathrm{m}^{2}$ in the area traversed by the present transect.

Apart from this crowded population of $O$. fragilis the epifauna in this area was poor, and the only other animals shown in the Iro interpreted frames 
(representing $275 \mathrm{~m} .^{2}$ ) were 30 Ophiocomina nigra, 5 Ophiura texturata, 5 Marthasterias glacialis, I Asterias rubens, I Echinus esculentus, 5 Eupagurus prideauxi, 5 Chlamys opercularis, 7 burrowing anemones, 3 hydroids and I clump of Cellaria sp. These figures suggest that very few other epifaunal invertebrates live in an area with a crowded population of brittle-stars. It was, however, noticed that the brittle-stars tend to avoid the area immediately surrounding a burrowing anemone; this is shown in Pl. I, fig. 4 .

\section{Area North-west of Eddystone, $\frac{3}{4}$ Mile, Depth $48 \mathrm{M}$.}

On I8 July I95I, R.V. Sabella was allowed to drift from position Eddystone bearing $147^{\circ} \mathrm{T}$., 0.73 miles, to Eddystone bearing $136^{\circ} \mathrm{T}$., $0.80 \mathrm{miles}$, while the first film was taken. The ship then steamed back to the first position and the second film was taken along the same transect.

The photographs on these two films show the greatest density of brittlestars recorded in the present investigation:

\begin{tabular}{|c|c|c|c|}
\hline $\begin{array}{l}\text { Total no. of } \\
\text { frames } \\
\text { interpreted }\end{array}$ & $\begin{array}{l}\text { No. of frames } \\
\text { with } \\
\text { O. fragilis }\end{array}$ & $\begin{array}{c}\text { Total no. of } \\
\text { O. fragilis }\end{array}$ & $\begin{array}{l}\text { Mean no. of } \\
\text { O. fragilis } \\
\text { per } \frac{1}{4} \mathrm{~m}^{2} \text { frame }\end{array}$ \\
\hline 36 & 36 & 3053 & 85 \\
\hline
\end{tabular}

This gives a mean density of $340 \mathrm{O}$. fragilis per m. ${ }^{2}$. These $36 \frac{1}{4} \mathrm{~m} .^{2}$ frames also contained 22 Ophiocomina nigra, I Marthasterias glacialis and I Echinus esculentus.

The photographs from this transect (Pl. I, figs. 5-7) show that the individual brittle-stars, although much more numerous, were also considerably smaller than those photographed in the other two brittle-star areas (south of Looe and area of Station L 4). The figure of 340 individuals per $\mathrm{m}^{2}$ may be regarded as a minimum, since in most frames the brittle-stars were living on top of each other, and the counts made could only reckon the top layer and those disks of animals in the lower layer which were not obscured by the tangled arms of the top layer.

\section{DISTRIBUTION OF OPHIOCOMINA NIGRA}

The black brittle-star, O. nigra, is common in the Plymouth area, but never in such large numbers as Ophiothrix fragilis, with which it is nearly always associated in dredge and trawl hauls. The present series of photographs gives an opportunity of determining the proportions in which it occurs in these mixed populations. From the figures in Table II it appears that there is, on the average, less than I Ophiocomina nigra to roo Ophiothrix fragilis. 


\begin{tabular}{|c|c|c|c|c|}
\hline & $\mathrm{TA}$ & LE II & & \\
\hline Date & Locality & O. fragilis & O. nigra & $\begin{array}{l}\text { Percentage of } \\
\text { O. nigra in } \\
\text { total } \\
\text { brittle-star } \\
\text { population }\end{array}$ \\
\hline 24. xi. 50 & S.W. of Rame Head & 547 & 2 & 0.4 \\
\hline I5. ii. $5 \mathrm{I}$ & S.W. of Rame Head & 436 & 0 & 0 \\
\hline 24 . iv. 5 I & S. of Looe Island & 763 & I & 0.1 \\
\hline 25. vii. $5 \mathrm{I}$ & S. of Looe Island & 3143 & 30 & 0.95 \\
\hline I8. vii. 5 I & N.W. of Eddystone & 3053 & 22 & 0.72 \\
\hline
\end{tabular}

\section{Discussion}

There is now no doubt that the dense population of Ophiothrix fragilis, 5 miles south of Looe Island, is not a seasonal phenomenon and that it is of a more permanent nature. Photographs of these brittle-stars have been taken on three different occasions in I950-I, and from them it appears that this population is at least 2 miles in length and $\frac{1}{2}$ mile in breadth, and it may be considerably larger. The mean density of brittle-stars in this area, calculated from the large number of photographs taken on the three transects, is about 97 per m. ${ }^{2}$, or 392,000 per acre. The amount of food, in the form of animal and plant detritus, consumed by such a population must be very large, and further work is in progress to determine the food requirements of this type of detrituseating brittle-star.

In the Ophiothrix population living $\frac{3}{4}$ mile north-west of Eddystone the minimum figures are 340 per $\mathrm{m}^{2}$ or about $\mathrm{r} \cdot 3$ million per acre; here the individual brittle-stars were somewhat smaller than those in the population south of Looe Island. These photographs were taken, by chance, in the middle of Allen's (I899) Ground X, coarse gravel and muddy sand, which he speaks of as characterized 'by the very great abundance of $O$. fragilis, which occurs almost to the exclusion of every other species'. His catches were taken with a dredge so that he had no exact measure of abundance, but there is little doubt that his Ophiothrix ground sampled at the end of the nineteenth century is essentially the same as that photographed in I95I.

The permanent nature of these brittle-star populations suggests that they rely for their food supply more on a steady flow of suspended material than on a settled bed of living or dead organic matter. It is possible that much of this suspended matter is carried back and forwards over the Ophiothrix bed by the tidal streams, and the position of the Looe and Rame beds at 5 and 4 miles respectively from the coast would favour this. The tidal streams in the neighbourhood of Eddystone are well known, and they would also tend to gather suspended material and carry it over the massed brittle-stars with their food-collecting net of tangled arms. 


\section{SUMMARY}

An improved underwater photographic apparatus has been used to take further series of photographs of the sea bottom near Plymouth. The photographs in the present series are each $\frac{1}{4} \mathrm{~m} .{ }^{2}$ in area instead of $\mathrm{I} \mathrm{m.} .^{2}$, and at this scale definition is much better.

Photographs of the bottom in the Rame Mud area showed ripple marks but no living epifaunal animals. In an area south of the Rame Mud, on a muddy sand and gravel bottom and in a similar area 6 miles south of Looe, dense populations of the brittle-star, Ophiothrix fragilis were photographed. In the area south of Looe this type of population (density more than Ioo individuals per $\mathrm{m}^{2}$ ) has been photographed on three different occasions in I950-I. In a similar but still denser Ophiothrix population found $\frac{3}{4}$ mile north-west of Eddystone, there were about 340 individuals per $\mathrm{m}^{2}$, and this aggregation was apparently of long standing, since exceptionally large dredge hauls of Ophiothrix were taken there in the last decade of the nineteenth century. It is suggested that the food supply for these populations, in the form of suspended material, is brought to them largely by the tidal streams and that the crowded beds are in localities where this is likely to happen.

From the photographic data it appears that in these dense populations of brittle-stars there is rather less than I Ophiocomina nigra to Ioo Ophiothrix fragilis.

\section{REFERENCES}

Allen, E. J., I899. On the fauna and bottom-deposits near the thirty-fathom line from the Eddystone Grounds to Start Point. Fourn. Mar. Biol. Assoc., Vol. 5, pp. $365-542$.

Vevers, H. G., I951. Photography of the sea floor. Fourn. Mar. Biol. Assoc., Vol. 30, pp. IOI-II. 


\section{EXPLANATION OF PLATE I}

Underwater photographs, each covering $\frac{1}{4} \mathrm{~m} .{ }^{2}$ of the sea bottom.

Figs. I-4. Showing samples from a dense population of Ophiothrix fragilis, 5 miles south of Looe Island. Density of over Ioo brittle-stars per m. ${ }^{2}$. In fig. 4 a burrowing anemone (where lines $a$ and $b$ cross) appears in a clearing among the brittle-stars. Depth $55 \mathrm{~m}$.

Fig. 5-7. Showing samples from a dense population of $O$. fragilis, $\frac{3}{4}$ mile north-west of Eddystone. Density of about 340 brittle-stars per $\mathrm{m}^{2}{ }^{2}$; individual brittle-stars smaller sized than in figs. I-4. In fig. 6 the bottom is rock and a single Echinus esculentus is attached to a vertical face. In fig. 7 the bottom is shell gravel. Depth $48 \mathrm{~m}$.

Fig. 8. Barren ground of muddy sand and gravel with shell fragments but no living epifaunal invertebrates. One mile west of Station L4. Depth $54 \mathrm{~m}$. 

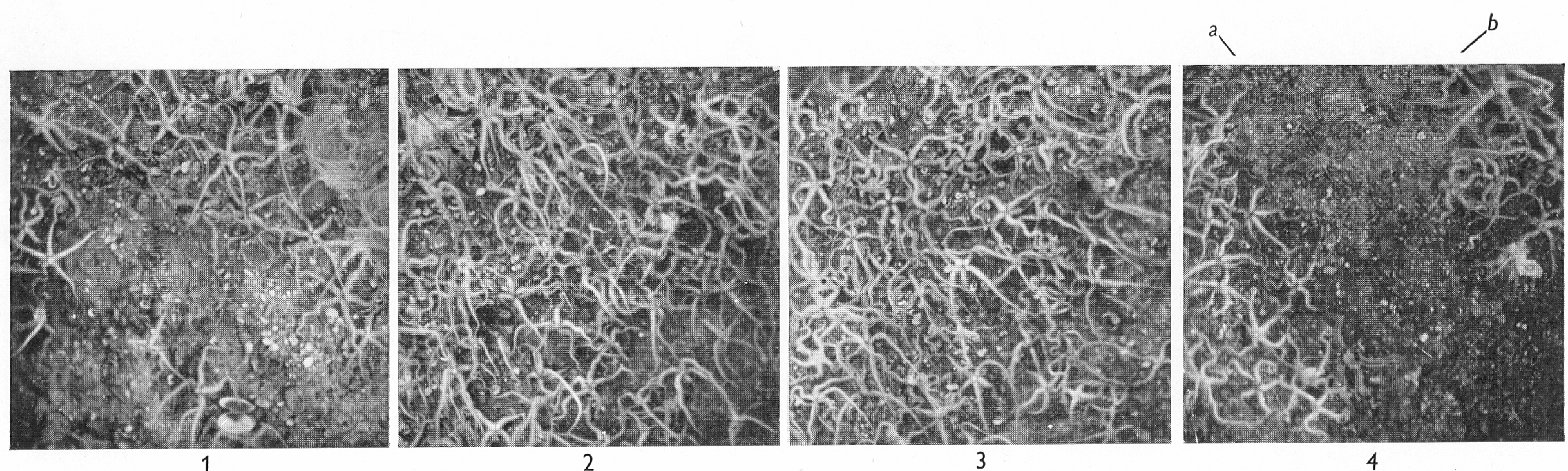

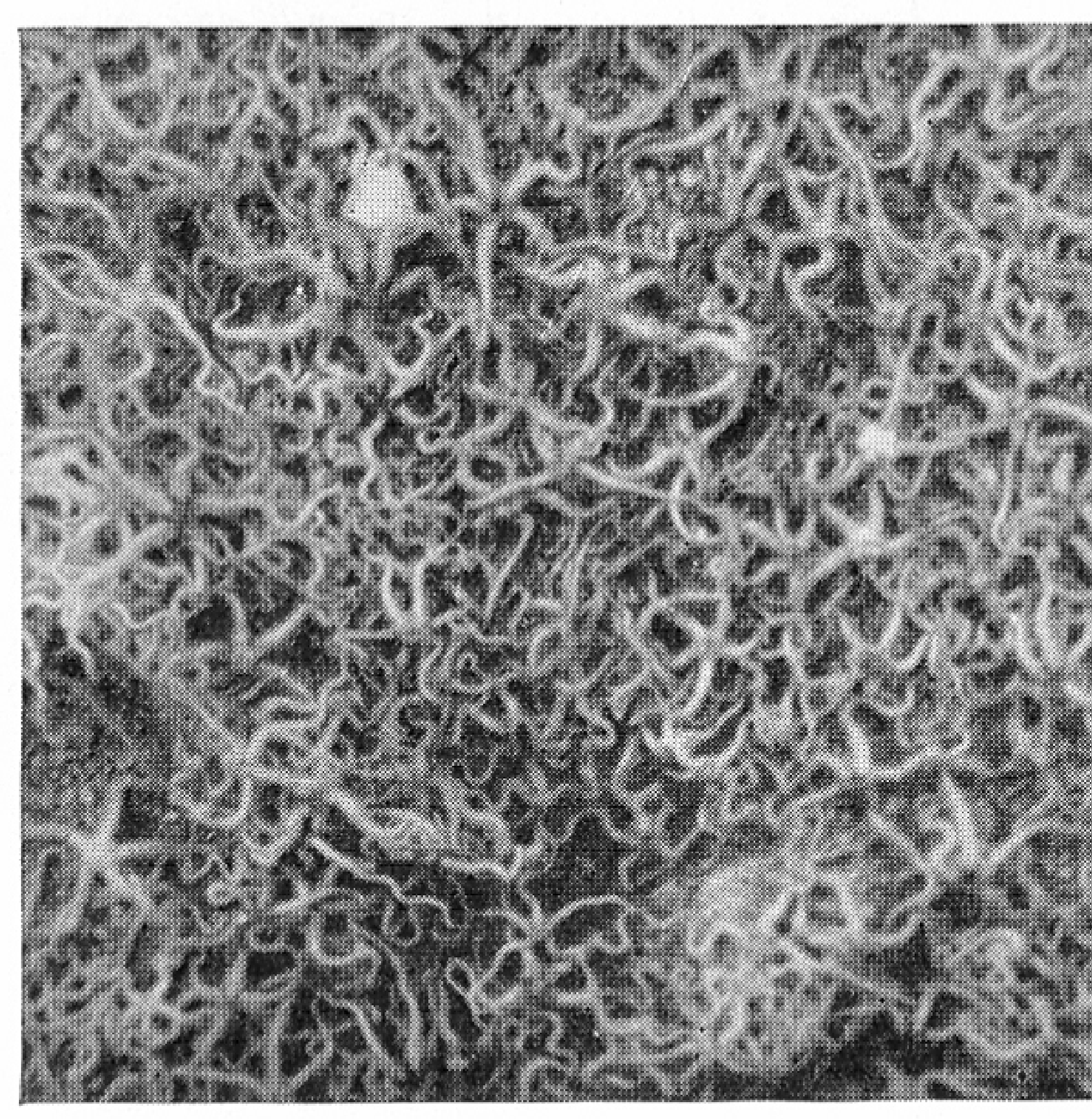

5

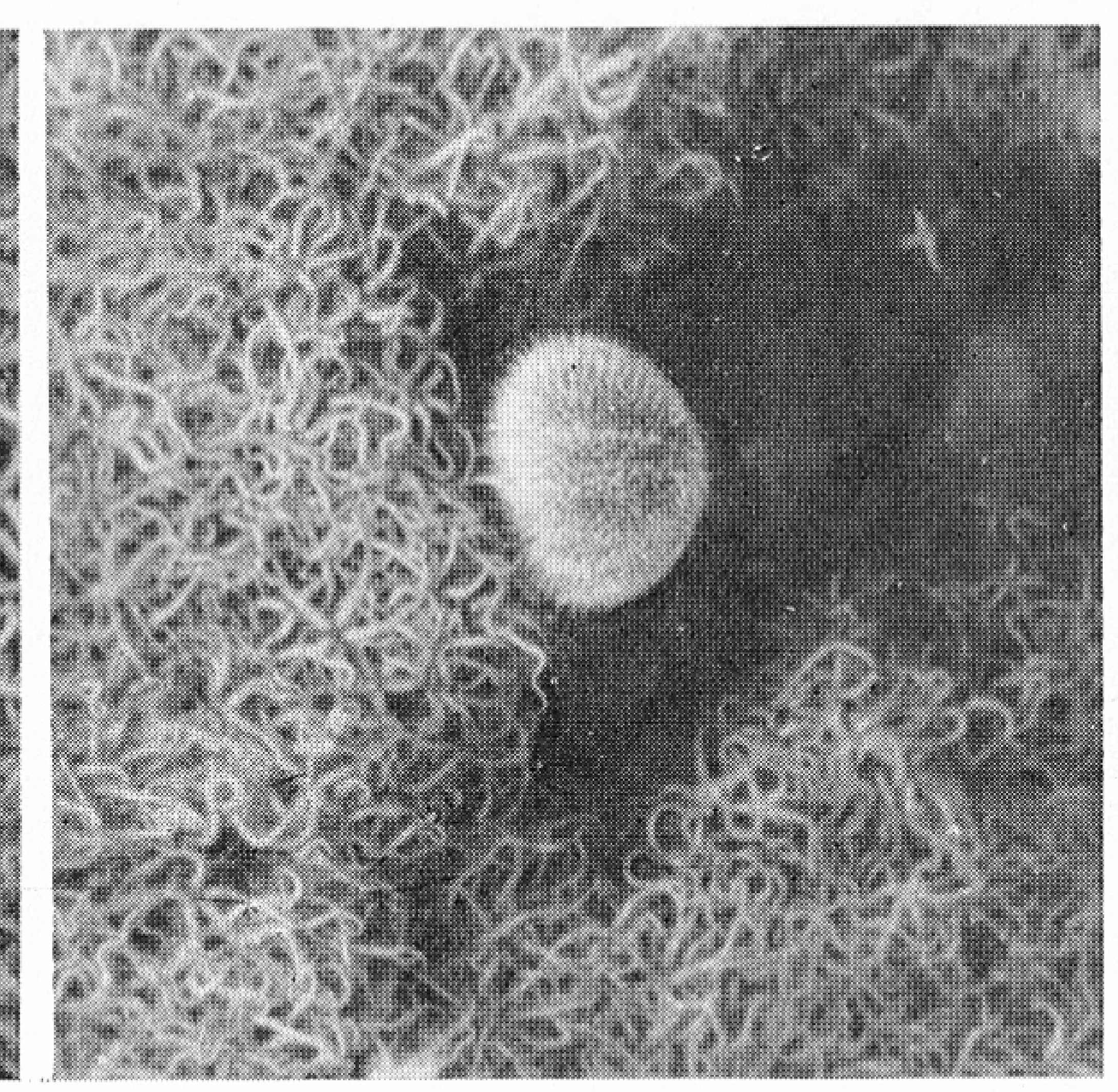

6

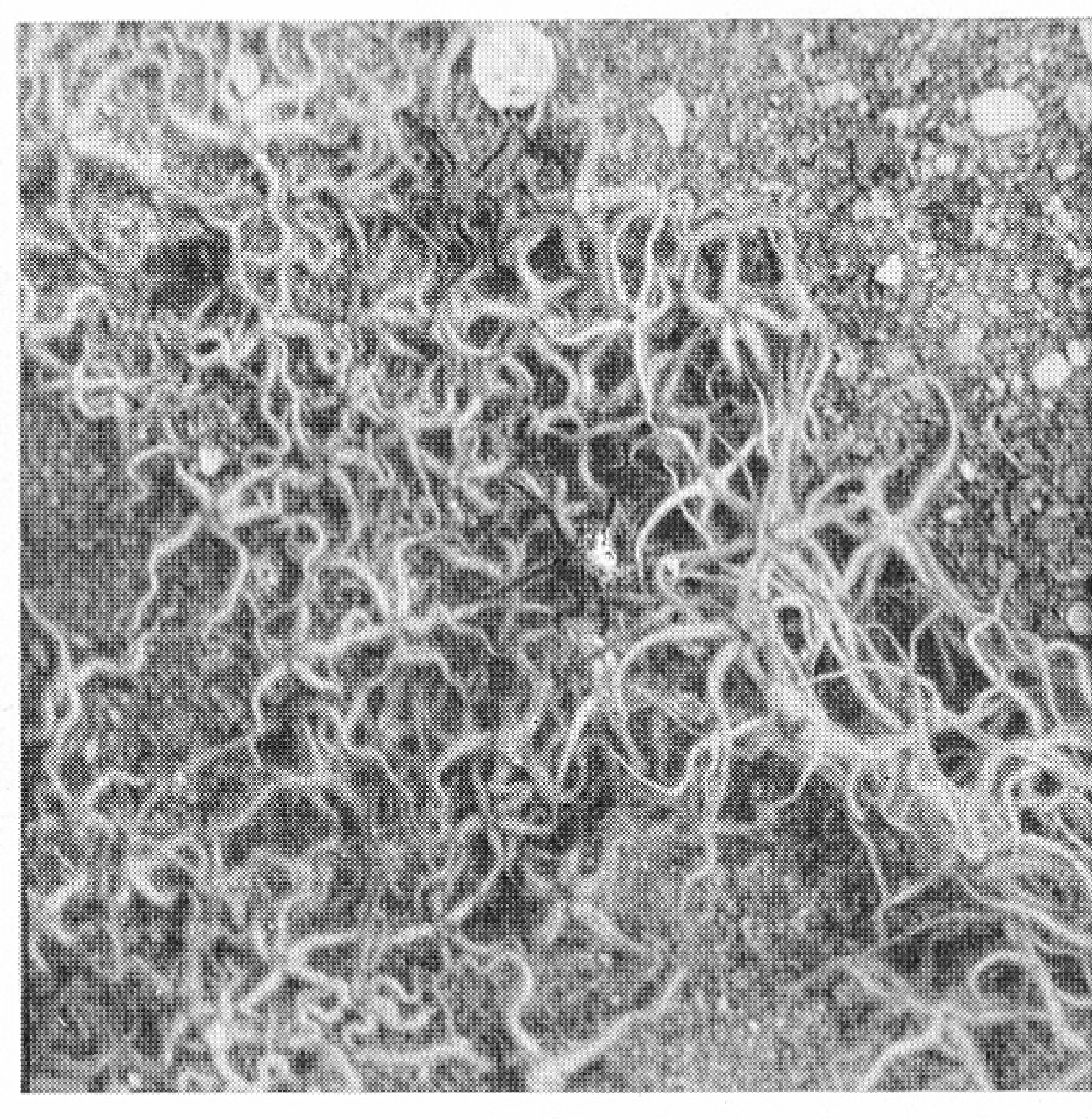

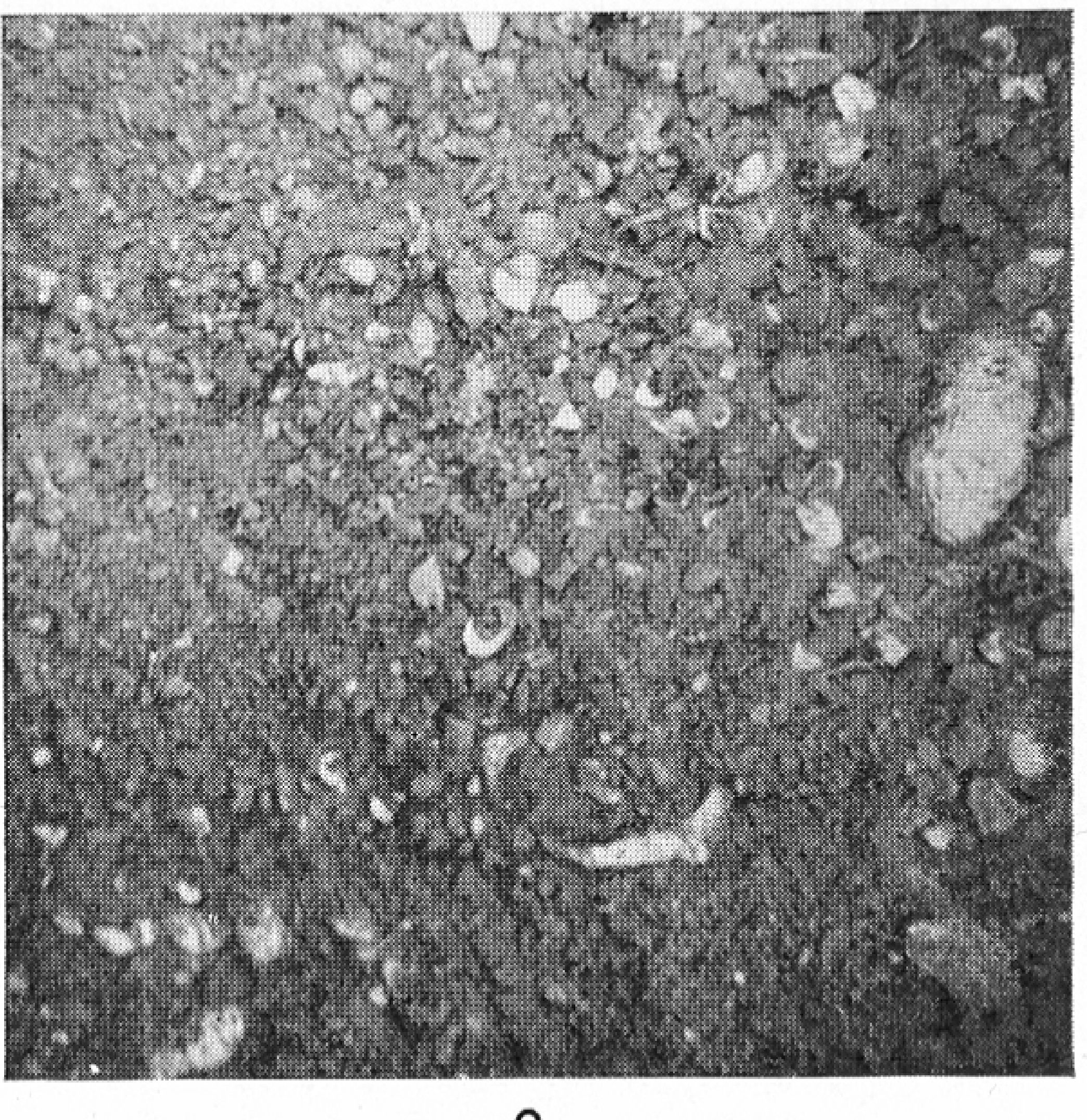

8 